\title{
Hygenic Study of Afghanistan Geologic Situation of the Afghan Cities
}

By

\author{
Hisa Suwa
}

Shitaya Hospital (President; Keigo Uchiyama)

Mutual Aid Association of Private School, Tokyo

As well known, human life could not be imagined without relation with the earth. That means the inhabited area by human kind; cities, towns and villages, should be studied from the point of view of earth science; geology, and their suitability for human living should be decided after the geologic and hydrologic informations.

In this chapter, the writer is intending to treat the hygenic situation of the principal cities in Afghanistan from the side of these informations.

The important physical property of the soil is permeability and preserving capacity for water. When grain size of the soil is large and contains larger amount of air, permeability is bigger and soil becomes easily dry to be suitable for housing site. However, in some cases, the large permeability causes pervasion of contaminated water and contamination of drinking water.

Smaller grain size and smaller amount of contained air cause larger preserving capacity of water and could be often unhealthy conditions.

The height of ground water level has relation with hygenic condition of a ground. Generally speaking, a ground with ground water level of $5 \sim 6 \mathrm{~m}$ or more from the surface is considered healthy, while of $1.5 \mathrm{~m}$ or less unhealthy. A ground with very variable ground water level is also unhealthy.

Subsurface temperature of a ground has intimate relation with temperature of drinking water from ground water. The temperature of a ground near surface is chiefly affected with absorption of solar heat. However, as the ground has low conductivity for heat, only surface layer of ca. $1 \mathrm{~m}$ in depth shows thermal variation affected by sun.

The subsurface layer of ground to $1 \mathrm{~m}$ in depth has daily change of temperature, to $10 \mathrm{~m}$ annual variation. Both of these changes decrease harply with increasing depth, increasing in arithmetical progression corresponding to thermal variation in geometrical progression.

Physical and chemical property of soil components affects suitability of ground water for drinking purpose. When the soil contains large amount of organic matter, the soil decreases in its self purifying capacity, water contains ammonia, salts, bacteria and other organic matters, becomes dirty with bad smell and unsuitable to drink.

The ground-soil with insufficient jquantity of calcium and magnesium causes ground water with scanty content of these elements to be a reason to produce insufficient development of bones of inhabitans. 
The ground from which some volatile gas comes out can be unhealthy for human body in some cases.

The ground-soil has an intimate relation with human life in the point that it composes a world in which bacteria, insects, reptiles, birds and other animals live. For example, some kinds of bacteria can live for long time in garden soil to cause very dangerous disease for human body.

1; Atghan principal cities and their geologic situation:

The principal cities in Afghanistan with meteorologic observatories are; Kabul (capital), Jalalabad, Baghlan, Kunduz, Mazar-i-Sharif, Herat, Kandahar and Ghazni. Among them, Kabul and Ghazni are on high plateau, the former being in a basin and the latter on northern margin of big plain. Other six cities are situated amidst or at margin of flat plain. Some geologic informations on situations of each city will be described as follows; (figures given herewith for longitude, latitude and altitude are estimated ones)

1; Kabul: ca. $69^{\circ} 20^{\prime} \mathrm{E}-34^{\circ} 40^{\prime} \mathrm{N}, 1,800 \mathrm{~m}$ high.

This capital is situated amidst of old lake basin surrounded by the high $(3,000 \sim 4,000$ m) mounatains of Paleozoic and Pre-Cambrian (?) gneiss. The basin is composed of rather thick (ca. $100 \mathrm{~m}$ or more) lake deposit of gravel, sand and loess. Gravel forms very hard conglomeratic layers cemented with calcareous matters which could be brought by ground water with high content of calcium. These gravel beds are good reservor for water, and water supply for: the capital (completed recently with success by Japanese engineers and firm) has its source in the water contained in these gravel beds. And so the water in Kabul city has high ratio of calcium contained in it.

Ground water level in Kabul is rather shallow, in southern area of the city being 1 $2 \mathrm{~m}$ and in northern and southeastern margin of the Kabul basin being $0 \mathrm{~m}$ from the surface.

The surface of the ground of the city is covered with a kind of loess (silt), light grey in color. It absorbs water easily and has some plastic character when it is wet.

2; Jalalabad; ca. $70^{\circ} 25^{\prime} \mathrm{E}-34^{\circ} 25^{\prime} \mathrm{N}$, ca. $400 \mathrm{~m}$ high.

This city is capital of Eastern Prdvince, situated between Kabul and Afghan-Pakistan border. The city is on the River Kabul, a tributary of the Indus. It is at the northern margin of a plain composed of a flat talus on the northern foot of the high (over 3,000 m) mountain range of Koh-i-Safed ("White Mountains"). In western part of city, it has swampy area and ground water level is nearly $0 \mathrm{~m}$ from surface there.

No underground information is available yet at present. The plain surrounding the city is defined in west and north by hills and mountains of gneiss and limestone of Paleozoic (?), in south of schist, limestone anp granitic rocks. So the plain may have many layers of rather thick gravel beds with sand and loess as its underground formation, and ground water could be plenty in its quantity. Furthermore, the water may have character of less content of calcium compared with the case of Kabul, because 
the southern border of the plair is mountain of granitic rocks.

3; Baghlan; ca. $68^{\circ}+5^{\prime} \mathrm{E}-36^{\circ} 10^{\prime} \mathrm{N}, 600 \mathrm{~m}$ high.

This city is capital of Kataghan Province. It is situated at the southern margin of Afghan Turkestan plain. In south of the city, there is hilly mountain of Mesozoic limestone and mudstone. The city itself is amidst of plain of loess. The water supply work is not yet started here and no underground informotion available at present. However, considering the southern mountain rich in limestone, the ground water with high content of calcium could be available in sufficient quantity for the city.

4; Kunduz; ca. $68^{\circ} 50^{\prime} \mathrm{E}-36^{\circ} 45^{\prime} \mathrm{N}, 400 \mathrm{~m}$ high.

This city is a newly revived, modern and industrial center in northern Afghanistan. It is located near the margin of Afghan Turkestan plain, being amidst of flat plain and on the meandering Kunduz River, a tributary of River Amu-Darrya. It has swampy area on west. The greater part of the present city is on the terrace (covered with loess) several meters higher than the river level and the swamp. Water supply project is just now started by Japanese firm and engineers, subground information is not yet available, but enough quantity of water for the city may be found easily.

5; Mazar-i-Sharif; ca. $67^{\circ} 05^{\prime} \mathrm{E}-36^{\circ} 40^{\prime} \mathrm{N}, 300 \mathrm{~m}$ high.

This city is the largest city in Afghan Turkestan; a commercial center of Northean Afghanistan and capital of Mazar-i-Sharif Province. It is situated amidst of Afghan Turkestan and at the northern margin of hilly land of Lower Tertiary and Cretaceous (Uppermost Mesozoic) limestones. The city has not yet any water supply and the former prospectings for water gave rather negative information for its underground water resources. The ground water could be rather high in its calcium content as the supposed sources of water are so rich in limestone.

The ground of the city is covered with loess, which causes very deep muddy street in the city during winter and rainy season.

6; Herat; ca. $62^{\circ} 10^{\prime} \mathrm{E}-34^{\circ} 20^{\prime} \mathrm{N}, 400 \mathrm{~m}$ high.

The city is old cultural city with much influence of Persian culture and is now capital of Herat Province. It is situated amidst of plain of River Hari Rud. On the northern bank of the river, the city is on a composite talus on the foot of the northern Paleozoic (?) mountain range. Water supply of the city has succeeded recently to have enough and sweet water for the city with efforts of Japanese firm and engineers. The surface of the ground of the city is covered with loess and gravel.

7.; Kandahar; ca. $65^{\circ} 35^{\prime} \mathrm{E}-31^{\circ} 35^{\prime} \mathrm{N}, 800 \mathrm{~m}$ high.

This city is capital of Kandahar Province and is developing rapidly as a modern industrial and commercial center of Southern Afghanistan. The construction of an ideal international airport is under way. Thiscity is expected to have very big possibility to be a large modern industrial city in this country.

It is situated on the southern foot of a mountain range of Mesozoic limestone which 
is a branch of the Hindukush Mountains (principal mountains of the country). Efforts to establish water supply for the city has been continued for several years by German engineers and firms. So many layers of gravel are known under the ground. But the situation of the city for the ground water ways is considered not so favorable. The ground is ccvered with loess and scatterd limestone gravels.

8; Ghazni, ca. $68^{\circ} 25^{\prime} \mathrm{E}-33^{\circ} 35^{\prime} \mathrm{N}, 2,200 \mathrm{~m}$ high.

The cityis capital of Ghazni Region, old capital of historic kingdom, and now a small center of local commerce. It is situated at the northern margin of a big plain stretching to Kandahar over $350 \mathrm{~km}$ in length of NE-SW direction. It is surrounded by the mountains of Paleozoic (?) gneiss and granitic rocks in east, north and west. The ground is covered with loess on gravel bed of recent or Pleistocene deposit. Water supply project is not yet started here.

2; Afghan principal cities and hygenic characteristics of their ground;

The geologic situation of these cities were detailed in the former chapter. As known from these descriptions, all of the cities has a ground covered with thick or thin layers of loess (silt) colored in light grey. In winter-rainy reason, the silt forms deep mud layer on unpaved street and often mixed with considerable amount of urine from the house. In summer, dried silt easily adsorbs large quantity of urine and is mixed with excrement and is blown away in the sky by strong wind and small cyclone, specially in Northern Afghanistan. These conditions could be favorable for distribution of parasites.

At some parts of several cities as Kabul, Jalalabad and Kunduz, the ground water level is very shallow from the surface, forming swampy areas around the cities. Several years ago, some cities, for example as Kunduz, were host of malaria. In Afghanistan there was a story that anybody who wishes to die should go to Kunduz. The swampy area and high temperature in summer in this city could be favorable conditions for malaria. After great effort of Afghan Government and WHO, however, malaria is now very seldom through the country.

The ground water in almost all of the principal cities in Afghanistan is pure and sweet. But as the country and the cities have so much quantity of limestone in itself and around them, the reservor layers of water are usually very rich in lime content. If a man not familiar with Afghan unboiled water drinks it, he may have some trouble in his abdomen for the first several days or several months. It is considered to be caused by high content of calcium in the water.

Surface water on and through surface soil (in general, loess-silt) should be considered contaminated in general case in the cities as described before.

At Mazar-i-Sharif and Kunduz in Northern Afghanistan, often they have sandstorm continuing for several days. During these days, the people con not see sun through dust in the sky. This dust is loess which distributes all over the country. 
Conclusion;

The ground of the principal cities in Afghan is covered with loess-a kind of silt light grey in color. This silt changes into mud in rainy in season and is very absorbent in other seasons. So contamination of this soil is general case in the cities. In dry season the soil is often blown away into the sky as dust having possibility to distribute some parasites.

In some parts of the cities, ground water level is so shallow to form swamps, but after hygenic efforts of Afghan Government and WHO, there is only seldom case of malaria to-day.

Ground water in those cities is generally high in its calcium content.

Surface water on and through the loess is generally contaminated in the cities.

Special gratitude of the writer should be presented to Dr. Uchiyama, President of Shitaya Hospital, who kindly took the trouble to read to correct the paper and Dr. Sawata who gave informations to the writer. 


\title{
RACE HYGIENE
}

\author{
Vol. 25, No. 6
}

November, 1959

\section{Correlation between Permanent Stature and Menarcheal Age}

By

\section{Mitsuru Suzumura}

Data about standing height mesurements and menarchieal ages examined in 158 healthy pregnant women have been studied. The outstanding findings are as follows:

1. There is a significant positive correlation $(+0.13)$ between reported menarcheal age and standing height in 158 women born in 1924 1940.

2. The correlation between menarcheal age and height of 73 women born in 1933 1936 was more significantly positive $(r=+0.40)$

3. The menarcheal age, in the average, annualy tend toward earlier, and the average height tend toward taller.

\section{(From the Department of Hygiene, Faculty of Medicine, Nagoya University)}

Hygenic Study of Afghanistan Geologic Situation

of the Afghan Cities

$\mathrm{By}$

\section{Hisa Suwa}

The writer treated herewith geologic situation of the Afghanistan in relation with hygenic conditions of them.

The ground of the prinicpal cities of Afghanistan is covered with a kind of loess-an aeolian soil, silt in grain size and light grey in color. This loess easily changes into mud during rainy season, and is very absorbent in other seasons. Afghan houses in the city have their toilets open to street or lane. Under these conditions, contamination of this soil on the ground is general case in the Afghan cities.

In dry season the loess is often blown away into the sky as dust having possibility to ditribute some parasites.

Suface water in the cities is generally contaminated.

In some parts of the cities, ground water level is so shallow to from swamps, but after hygenic efforts of Afghan Government and WHO, there is very seldom case of malaria to-day in Afghanistan.

Ground water in those cities is generally high in its calcium content.

(From Shitaya Hospital, Mutual Aid Association of Private School TOKYO) 